Original Article

\title{
FORMULATION AND CHARACTERIZATION OF MATRIX TABLETS USING MUCILAGE OF TINOSPORA CORDIFOLIA AS NATURAL BINDER
}

\author{
REECHA MADAAN, RAJNI BALA, TEJESWINI VASISHT, RITIMA SHARMA, SHIVALI GARG
}

Chitkara College of Pharmacy, Chitkara University, Rajpura, Punjab 140401

Email: rajni.bala@chitkara.edu.in

Received: 23 Feb 2018 Revised and Accepted: 01 Jun 2018

\begin{abstract}
Objective: The present research work was to formulate matrix tablets of diclofenac sodium using mucilage extracted from Tinospora cordifolia as a novel binding agent. Also, a comparative study on binding properties of mucilage and carbopol were performed.

Methods: Fresh stems of Tinospora cordifolia were collected and mucilage was extracted out using standard method. The isolated mucilage was characterised for physicochemical parameters. Formulation of diclofenac sodium tablets (f1-f6) was done by dry granulation method using $2 \%$, 4\%, $6 \%, 8 \%$ and $10 \%$ concentration of mucilage of Tinospora cardifolia as natural binder. Carbopol $2 \%$ was used as synthetic matrix forming agent. Microcrystalline cellulose was used as diluents, magnesium stearate and talc as lubricant. The formulated tablets were evaluated for parameters such as tablet thickness, hardness, weight variation, disintegration time, percent friability and in vitro drug release characteristics. The drug release mechanism was determined by fitting the release data into different kinetics models.

Results: The results revealed that all the pre and post compression parameters of the formulated tablets (f1-f6) were in compliance with pharmacopoeial limits. In vitro drug release studies showed that formulation f6 containing maximum concentration of mucilage release the drug in a most controlled and sustained manner with maximum drug release of $63.6 \%$ in $15 \mathrm{~h}$ in comparison with $\mathrm{f} 1(2 \%$ carbopol) giving $80 \%$ release and was found to be stable for 3 mo as indicated by stability studies. The mechanism of drug releases from formulation f1-f6 was found to be polymer disentanglement and erosion. Preformulation studies using FTIR study reveals that there is no incompatibility between the pure drug and mucilage of tinospora cardifolia used.
\end{abstract}

Conclusion: Based on the experimental findings it can be concluded that Tinospora cordifolia mucilage can be used as a release retardant agent in the formulation of sustained release dosage forms.

Keywords: Tinospora cordifolia, Natural polymer, Matrix tablets

(C) 2018 The Authors. Published by Innovare Academic Sciences Pvt Ltd. This is an open access article under the CC BY license (http://creativecommons.org/licenses/by/4.0/) DOI: http://dx.doi.org/10.22159/ijpps.2018v10i7.25447

\section{INTRODUCTION}

In pharmaceutical dosage form various excipients and additives are mixed together to form a suitable dosage form for patient administration [1]. Each and every excipient has its own role to determine the quality and bioavailability of drug and binder is also one of the important excipient in tablet formulation [2]. Binders are the agents which hold various powders together to form a tablet. They impart cohesiveness to the granules to improve compression and flow properties which derived the hardness of tablet [3]. Different binders have different mechanical strengths and drug release properties to achieve different pharmaceutical purposes. While formulating the tablet, extensive knowledge of binder properties for enhancing the strength and also the interaction between various materials constituent should also be considered. This is the reason that development of new excipients as tablet binder is of continuous interest. Different types of polymers both natural and synthetic are used as binders in tablet formulation. Natural binders like starch, gums and mucilage are used widely due to their low cost, less toxicity, biocompatibility and environmental friendly processing $[4,5]$. In the present work, an attempt has been made to formulate matrix tablets of diclofenac sodium an effective anti-inflammatory, analgesic and antipyretic drug. It has short biological half-life of $1.2-2 \mathrm{~h}$ due which it is rapidly eliminated from the system so it would be a great advantage to formulate it as controlled released dosage form using mucilage extracted from fresh stems of Tinospora cordifolia (Menispermaceae). The objective of the work was to explore a novel natural binding agent and to formulate sustained released tablets of diclofenac sodium so as to reduce its frequent administration and to enhance patient compliance. Hence the novelty of the proposed work is the use of tinospora cardifolia mucilage as matrix forming agent to retard the release of drug.

\section{MATERIALS AND METHODS}

\section{Materials}

Fresh stems of Tinospora cordifolia were collected locally from Rajpura, Punjab. Authentication of the sample was confirmed from Punjabi University Patiala, India and voucher specimen no is $03 / 2017 / C C P$ (chitkara university, Punjab). Diclofenac sodium was obtained from Yarrow Chem Mumbai, India, carbopol from Ozone international Mumbai India, Magnesium stearate and talc used were of Loba Chem.

\section{Isolation of mucilage}

Fresh stems of Tinospora cordifolia was collected and thoroughly washed with water to remove impurities. The stem was sliced into half and then cut into small pieces. It was crushed and mixed with distilled water in a beaker and placed on the heating mantle at $100^{\circ} \mathrm{C}$ for four hours. The mass was kept soaking overnight. After $12 \mathrm{~h}$ the mass was filtered with muslin cloth and liquid was kept undisturbed. Carefully, the supernatant was decanted and collected in a separate beaker. Acetone was added slowly to the filtrate till precipitation is completed. The precipitate mucilage was separated and washed thrice with acetone to remove the traces of water. The separated mucilage was spread on a glass plate and dried at $45 \pm 0.5^{\circ} \mathrm{C}$. Dried mucilage was grinded and passed through sieve no. \#60 and was stored in air tight container [6, 7].

Physicochemical evaluation of mucilage

The isolated mucilage was evaluated for various physicochemical properties [8].

\section{Drug excipient compatibility studies}

Drug excipient compatibility studies were performed using Fourier transforms infra-red (FTIR) spectroscopy. FTIR spectra of the diclofenac 
sodium, Tinospora cordifolia mucilage and combined mixture (1:1) of both were taken (Bruker Alpha T) within the range of 3500-500 $\mathrm{cm}^{-1}$

\section{Standard calibration curve of Diclofenac sodium}

To plot standard calibration curve of diclofenac sodium $100 \mathrm{mg}$ of drug was weighed and transferred to $100 \mathrm{ml}$ of volumetric flask and $10 \mathrm{ml}$ of methanol was added to dissolve the drug and the volume was adjusted to $100 \mathrm{ml}$ using $0.1 \mathrm{~N} \mathrm{HCL}$ (stock I). $10 \mathrm{ml}$ of solution was withdrawn from stock I to $100 \mathrm{ml}$ volumetric flask and volume was made up to 100 ml using $0.1 \mathrm{~N}$ HCL (stock II). Stock II was then used to prepare working standards by pipetting out $0.2,0.4,0.6,0.8,1 \mathrm{and} 1.2 \mathrm{ml}$ of solution in 10 $\mathrm{ml}$ volumetric flask and finally the volume was adjusted to $10 \mathrm{ml}$. The absorbance of the resulting solution was measured at $276 \mathrm{~nm}$ using UVVS spectrophotometer [9].

\section{Formulation of diclofenac sodium tablets}

Formulation of diclofenac tablets was done by dry granulation method. Microcrystalline cellulose was used as diluents, magnesium stearate and talc as lubricant respectively. $2 \%, 4 \%$, $6 \%, 8 \%$ and $10 \%$ concentration of mucilage of Tinospora cardifolia was used as binder. All ingredients were weighed as per the composition given in the table 1 and passed through the sieve no.40 and mixed uniformly in geometrical order. The formulated blend was then subjected to compression to form slugs of hardness $4-4.5 \mathrm{~kg} / \mathrm{cm}^{2}$. The slugs are then milled to granulate and screened through 22/44 mesh. Granules retained on sieve no. 44 were lubricated and evaluated for various pre compression parameters. For comparison carbopol $2 \%$ was used as synthetic matrix forming agent.

\section{Pre compression parameters}

The formulation blends was characterized for pre compression parameters such as bulk density, tapped density, angle of repose and \% compressibility to assess their flow behaviour and were compressed in to tablets using double punch tablet compression machine of weight equivalent to $200 \mathrm{mg}$ [10].

Table 1: Composition of diclofenac sodium matrix tablets formulation (mg)

\begin{tabular}{|c|c|c|c|c|c|c|}
\hline Ingredients & f1 & f2 & f3 & f4 & f5 & f6 \\
\hline Diclofenac & 50 & 50 & 50 & 50 & 50 & 50 \\
\hline Talc & 5 & 5 & 5 & 5 & 5 & 5 \\
\hline Magnesium Stearate & 5 & 5 & 5 & 5 & 5 & 5 \\
\hline Micro crystalline cellulose & 132 & 132 & 128 & 124 & 120 & 116 \\
\hline Carbopol & $2 \%$ & - & - & - & - & - \\
\hline \multirow[t]{2}{*}{ Mucilage total weight (mg) } & - & $2 \%$ & $4 \%$ & $6 \%$ & $8 \%$ & $10 \%$ \\
\hline & 200 & 200 & 200 & 200 & 200 & 200 \\
\hline
\end{tabular}

(Quantities in mg/tablet)

\section{Characterization of tablets}

The prepared sustained released matrix tablets were evaluated for various post compression parameters like physical appearance, weight variation, hardness, friability, and disintegration time as per the official procedure. The hardness of the tablets was evaluated by Monsanto hardness tester. For hardness at random three tablets were taken from each formulation batch and average of three measurements was taken. For friability numbers of tablets equivalent to $6.5 \mathrm{gm}$ were taken and placed in a friability chamber rotated at $25 \pm 1 \mathrm{rpm}$ for $4 \mathrm{~min}$ and the percentage of weight loss was determined as an indicator of friability. The disintegration test was performed in phosphate buffer $\mathrm{pH} 6.8$ at $37 \pm 0.5^{\circ} \mathrm{C}$. The disintegration time reported is an average of three determinations [11].

\section{In vitro dissolution study}

The in vitro dissolution study of the various tablet formulations was performed using the USP dissolution test apparatus II paddle type (Electrolab, India). The dissolution study was done by placing one tablet in $900 \mathrm{ml}$ of $0.1 \mathrm{~N} \mathrm{HCL}(\mathrm{pH} 1.2)$ as dissolution medium maintained at $37 \pm 0.5^{\circ} \mathrm{C}$ with a speed of $75 \mathrm{rpm}$.

The amount of drug released was estimated by removing the $5 \mathrm{ml}$ of dissolution medium at different time intervals, filtered (though 0.45 $\mu \mathrm{m})$, and absorbance was measured at $276 \mathrm{~nm}$ using Systronic double beam UV spectrophotometer [12].

\section{Drug release kinetics}

To determine the order and mechanism of drug release from the formulated matrix tablets, the in vitro release data was fitted to kinetic models viz; zero order, first-order, Higuchi square root equation and Korsmeyer Peppas model.

Q $1 / 4 \mathrm{Q}_{0}+\mathrm{k}_{0} \mathrm{t}$ (Zero order)

In $Q \frac{1}{4}=\operatorname{In} Q_{0}+k_{1} t$ (First order)

$\mathrm{Q}=\mathrm{K}_{\mathrm{H}} \mathrm{t}^{\mathrm{n}}$ (Higuchi)

$Q_{0}^{1 / 3}-Q_{R}^{1 / 3}=K_{s} t$ (Hixson-Crowell)
$\mathrm{Q} / \mathrm{Q}_{\mathrm{T}}=\mathrm{K}_{\mathrm{kp}} \mathrm{l}^{\mathrm{n}}$ (Korsmeyer-peppas)

Where $Q$ is amount of drug release at time $t, Q_{0}$ is the initial amount of drug, $Q_{R}$ is the amount of drug remaining at time $t$, and $Q_{T}$ is the total amount of drug release. $\mathrm{k}_{0}, \mathrm{k}_{1}, \mathrm{k}_{\mathrm{H}}$, ks and $\mathrm{K}_{\mathrm{kp}}$ are the kinetic constants for zero order, first order, Higuchi, Hixson-Crowell and Korsmeyer-Peppas models, respectively, and $\mathrm{n}$ is the release exponent [13-15].

\section{Stability study}

The stability studies of selected tablet batches were carried out in stability chamber (Remi Instruments, India) kept at $40 \pm 0.5^{\circ} \mathrm{C}$ and $75 \%$ RH conditions for three months. The effects of temperature and time on the physical characteristics and release profile of the tablet were evaluated to study the stability of the prepared formulations [16].

\section{RESULTS AND DISCUSSION}

\section{Physicochemical evaluation of mucilage}

The standard procedure was used to isolate mucilage from stems of Tinospora cordifolia. The total yield of mucilage by acetone precipitation method was found to be $15 \%$. The isolated mucilage was of greyish white colour, odourless, mucilaginous taste and amorphous in nature. The isolated mucilage was evaluated for various physicochemical properties and results are listed in table 2 .

\section{Standard calibration curve of Diclofenac sodium}

The standard calibration curve of diclofenac sodium was obtained by plotting absorbance versus concentration as shown in fig.1. The standard calibration curve shows the correlation coefficient of 0.990 .

\section{Drug-excipients compatibility studies}

FTIR spectra of diclofenac sodium, Tinospora cordifolia mucilage and mixture of drug and mucilage are given in fig. 2, 3 and 4. Spectral analysis indicated all the important peaks of drug in the FTIR of drug and mucilage which means that diclofenac sodium is functionally compatible with the mucilage. 
Table 2: Characterisation of Tinospora cordifolia mucilage

\begin{tabular}{|c|c|c|}
\hline S. No. & Properties evaluated & Observations \\
\hline 1. & Colour & Greyish white \\
\hline 2. & Odour & Odourless \\
\hline 3. & Taste & Mucilaginous \\
\hline 4. & Solubility & Forms colloidal solution in water and insoluble in ethanol and acetone \\
\hline 5. & $\%$ yield & $15 \%$ \\
\hline 6. & Average particle size $(\mu \mathrm{m})$ & $161.18 \pm 0.23^{*}$ \\
\hline 7. & Loss on drying & $10 \%$ \\
\hline 8. & Swelling ratio(in distilled water) & $8^{*}$ \\
\hline 9. & $\mathrm{pH}$ (By digital pH meter) & $6.2^{*}$ \\
\hline 10. & Ash Value (\%) & $2.1 \pm 0.02 *$ \\
\hline 11. & Viscosity ( $1 \%$ solution) & 353 cps* \\
\hline 12. & Surface tension $(0.1 \% \mathrm{w} / \mathrm{v})$ & $79.11 \pm 0.32$ dynes $/ \mathrm{cm}$ \\
\hline 13. & $\begin{array}{l}\text { Test for Carbohydrates } \\
\text { (Molisch's test) }\end{array}$ & $+\mathrm{ve}$ \\
\hline 14. & $\begin{array}{l}\text { Test for reducing sugar } \\
\text { (Fehling's solution) }\end{array}$ & $+\mathrm{ve}$ \\
\hline 15. & Test for Tannins (Ferric chloride test) & -ve \\
\hline 16. & Test for Glycosides & -ve \\
\hline 17. & Test for Starch & -ve \\
\hline 18. & Test for Terpenoids & -ve \\
\hline 19. & Test for Flavonoids (shinoda test) & $+\mathrm{ve}$ \\
\hline 20. & Test for saponins (foam test) & -ve \\
\hline 21. & Test for alkaloids (Mayer's test) & -ve \\
\hline 22. & Test for Mucilage(Ruthenium red test) & $+\mathrm{ve}$ \\
\hline 23. & Mucilage+Methylene blue & Deep blue (+) \\
\hline 24. & Mucilage+Aqueous $\mathrm{KOH}$ & Swell (+) \\
\hline 25. & Test for chlorides (silver nitrate test) & -ve \\
\hline 26. & Test for Sulphates (barium chloride test) & -ve \\
\hline 27. & Test for uronic acid & $+\mathrm{ve}$ \\
\hline
\end{tabular}

*Data are represented as mean \pm standard deviation $(n=3),+v e=$ Positive,-ve $=$ Negative

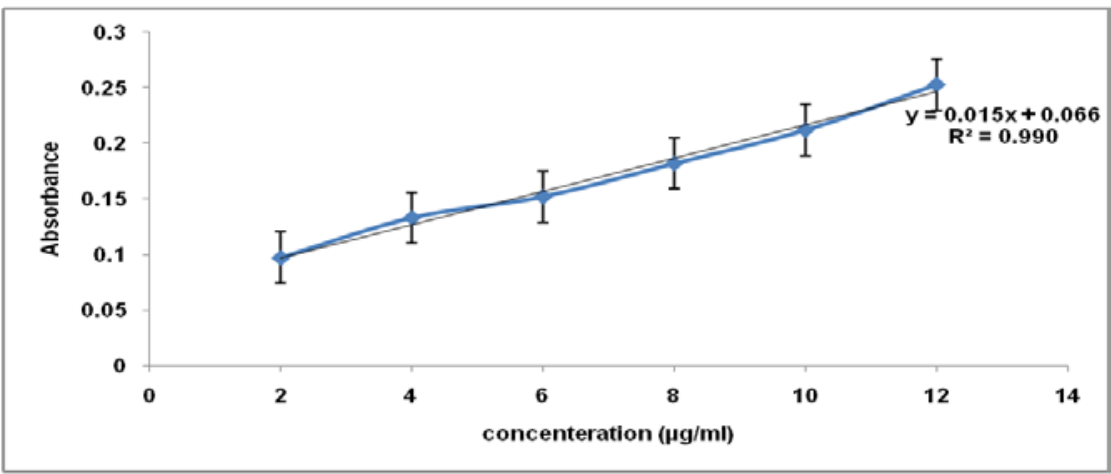

Fig. 1: standard calibration curve of diclofenac sodium

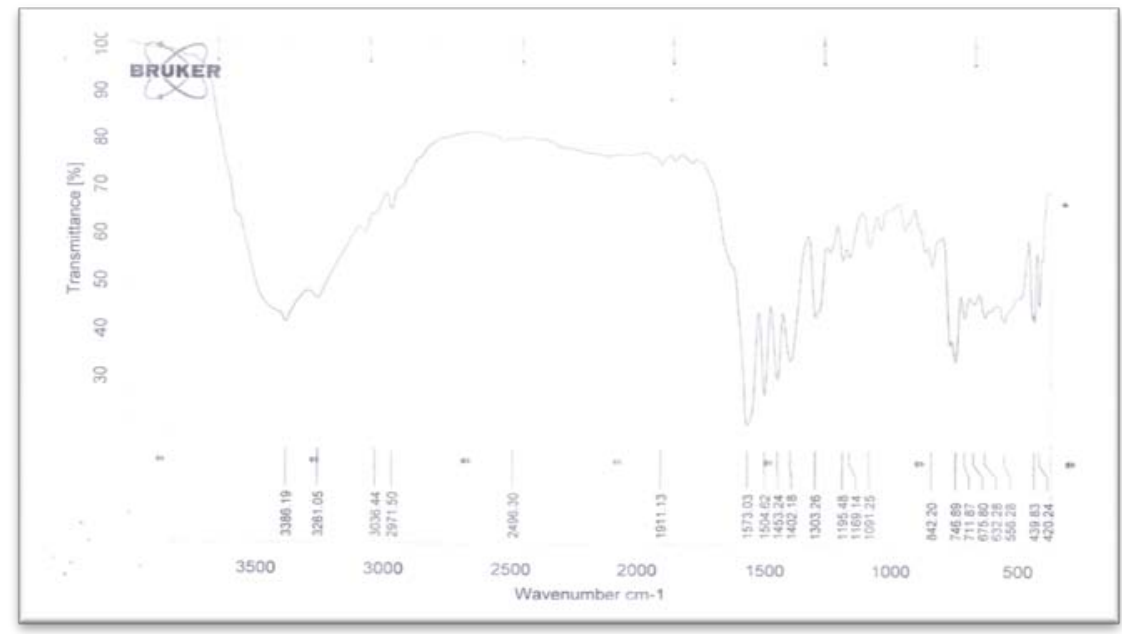

Fig. 2: FTIR of diclofenac 


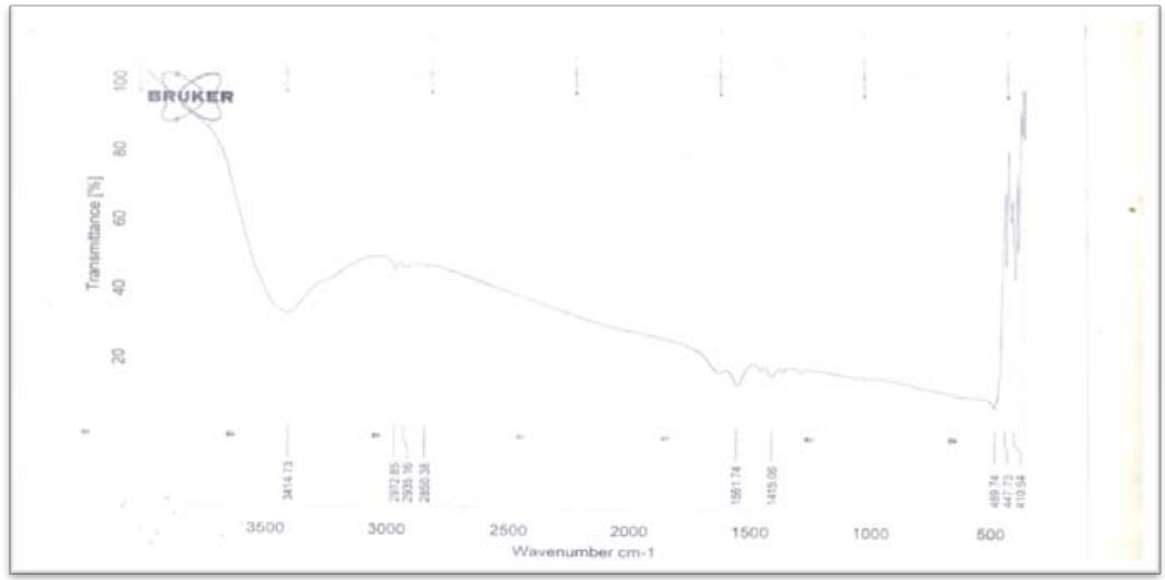

Fig. 3: FTIR of Tinospora cordifolia mucilage

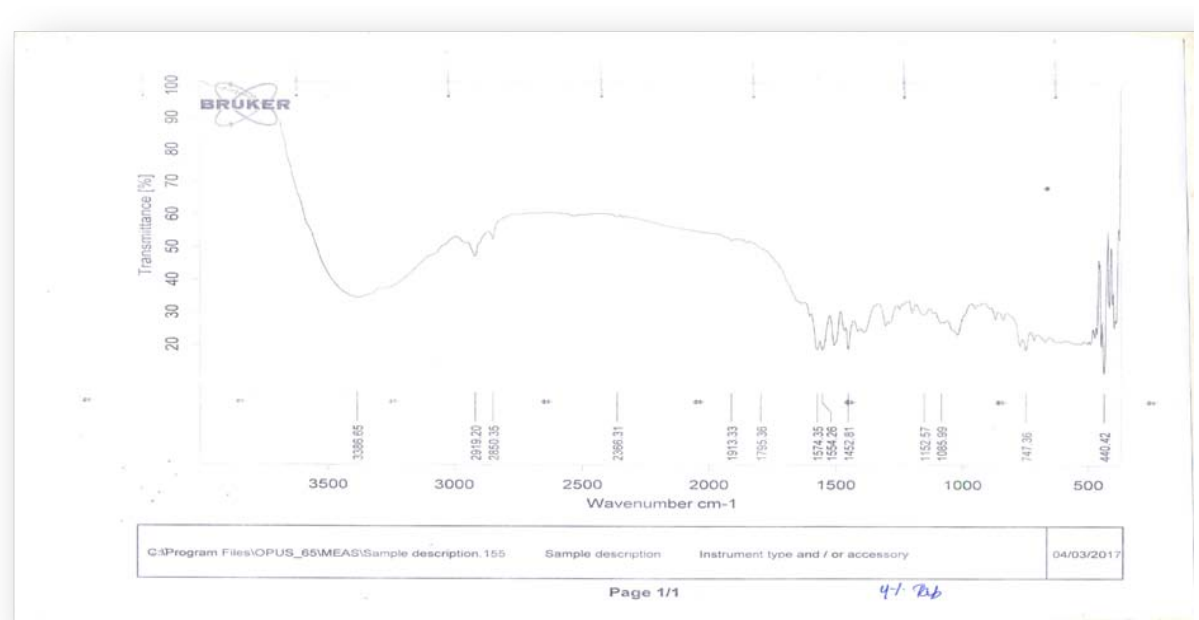

Fig. 4: FTIR of Tinospora cordifolia mucilage and diclofenac sodium

\section{Pre compression parameter}

Six different formulation batches of diclofenac sodium matrix tablets were prepared using different concentration of mucilage as a matrix forming agent to retard the drug release rate. The flowability of different formulation powder blend was assessed by using hausner ratio, Carr's index and angle of repose. Hausner ratio values ranging between $1.25-1.42$ appeared to indicate good flow characteristic. Carr's index $<16 \%$ of all formulations is indicative of good flow. In terms of angle of repose the value $<25^{\circ}$ ranging between 25.4-27.2 indicated average to good flowability. The results of pre compression characterisation of formulation blends (bulk density, tapped density, Carr's index) are shown in table 3 .

Table 3: Characterisation of formulation blends of diclofenac matrix tablets

\begin{tabular}{|c|c|c|c|c|c|}
\hline Formulation code & $\begin{array}{l}\text { Bulk density } \\
(\mathrm{g} / \mathrm{cc})^{\mathrm{a}}\end{array}$ & $\begin{array}{l}\text { Tapped density } \\
(\mathrm{g} / \mathrm{cc})^{\mathrm{a}}\end{array}$ & Angle of repose ${ }^{a}$ & Carr's Index & Hausnor ratio \\
\hline f1 & $0.572 \pm 0.01$ & $0.789 \pm 0.02$ & $25.6 \pm 0.21$ & 12.4 & 1.25 \\
\hline $\mathrm{f} 2$ & $0.514 \pm 0.11$ & $0.763 \pm 0.03$ & $27.2 \pm 0.11$ & 12.8 & 1.38 \\
\hline f3 & $0.557 \pm 0.02$ & $0.767 \pm 0.11$ & $26.8 \pm 0.05$ & 13.2 & 1.42 \\
\hline $\mathrm{f} 4$ & $0.571 \pm 0.10$ & $0.754 \pm 0.01$ & $27.5 \pm 0.23$ & 12.7 & 1.26 \\
\hline f5 & $0.563 \pm 0.01$ & $0.761 \pm 0.02$ & $25.4 \pm 0.01$ & 13.8 & 1.30 \\
\hline f6 & $0.523 \pm 0.02$ & $0.80 \pm 0.11$ & $26.2 \pm 0.02$ & 13.4 & 1.28 \\
\hline
\end{tabular}

amean $\pm \mathrm{SD}, n=3$

\section{Post compression parameter}

Microcrystalline cellulose was used in the formulation of sustained released matrix tablets of diclofenac sodium because of its versatility as direct compression excipient to improve the tablet ability of physical blend of the formulation. The average weight of all the formulations ranges between 199-206 mg which means all the formulations passed uniformity in weight test as per the pharmacopeia $( \pm 7.5 \%$ mean weight). All tablet formulations exhibit good mechanical strength with hardness ranging $4.3-6.0 \mathrm{~kg} / \mathrm{cm}^{2}$. Formulation f6 containing $10 \%$ of mucilage exhibit maximum hardness of $6 \mathrm{~kg} / \mathrm{cm}^{2}$. The friability test was carried out to measure the ability of tablets to withstand abrasion, chipping during handling, packaging and transportation and as per IP it should not 
exceed $1 \%$, all formulation showed percent friability in the range between $0.12-0.5 \%$ which means they passed the friability test as per the official specifications and has good mechanical resistance. Disintegration time increases as the concentration of mucilage increases, which may be due to strong binding potential of the increasing mucilage concentration and varies between 20-31 min, the results for characterisation are given in table 4 [17]. In vitro drug release decreases with increase in mucilage concentration. This may be due to the fact that at higher concentration of mucilage there is formation of dense matrix which reduces the mobility of drug particles and slow down the dissolution rate [18]. With f6 formulation giving $63.6 \%$ release after $15 \mathrm{~h}$ and formulation $\mathrm{f} 1$ containing $2 \%$ carbopol showed $80 \%$ release after $15 \mathrm{~h}$. In vitro drug release profile of all the formulation batches is shown in fig. 5 .

Table 4: Characterisation diclofenac sodium matrix tablet formulations

\begin{tabular}{|c|c|c|c|c|c|c|}
\hline $\begin{array}{l}\text { Formulation } \\
\text { Code }\end{array}$ & Weight variation (mg) & $\begin{array}{l}\text { Hardness } \\
\left(\mathrm{Kg} / \mathrm{cm}^{2}\right)^{\mathrm{a}}\end{array}$ & $\begin{array}{l}\text { Thickness } \\
(\mathrm{mm})^{\mathrm{a}}\end{array}$ & $\%$ friability & Disintegration time(min) $^{a}$ & Drug content $(\%)^{a}$ \\
\hline f1 & 201 & $4.3 \pm 0.27$ & $3.7 \pm 0.15$ & 0.5 & $20 \pm 0.01$ & $98.2 \pm 0.05$ \\
\hline $\mathrm{f} 2$ & 200 & $4.5 \pm 0.11$ & $3.2 \pm 0.02$ & 0.21 & $22 \pm 0.33$ & $99.4 \pm 0.12$ \\
\hline $\mathrm{f} 3$ & 205 & $4.6 \pm 0.23$ & $4.3 \pm 0.21$ & 0.3 & $24 \pm 0.24$ & $97.5 \pm 0.11$ \\
\hline $\mathrm{f} 4$ & 199 & $5.0 \pm 0.15$ & $4.7 \pm 0.02$ & 0.2 & $25 \pm 0.06$ & $99.3 \pm 0.25$ \\
\hline f5 & 200 & $5.3 \pm 0.22$ & $4.0 \pm 0.05$ & 0.3 & $30 \pm 0.32$ & $99.2 \pm 0.01$ \\
\hline f6 & 206 & $6.0 \pm 0.23$ & $3.7 \pm 0.21$ & 0.12 & $31 \pm 0.24$ & $98.7 \pm 0.21$ \\
\hline
\end{tabular}

amean $\pm \mathrm{SD}, n=3$.

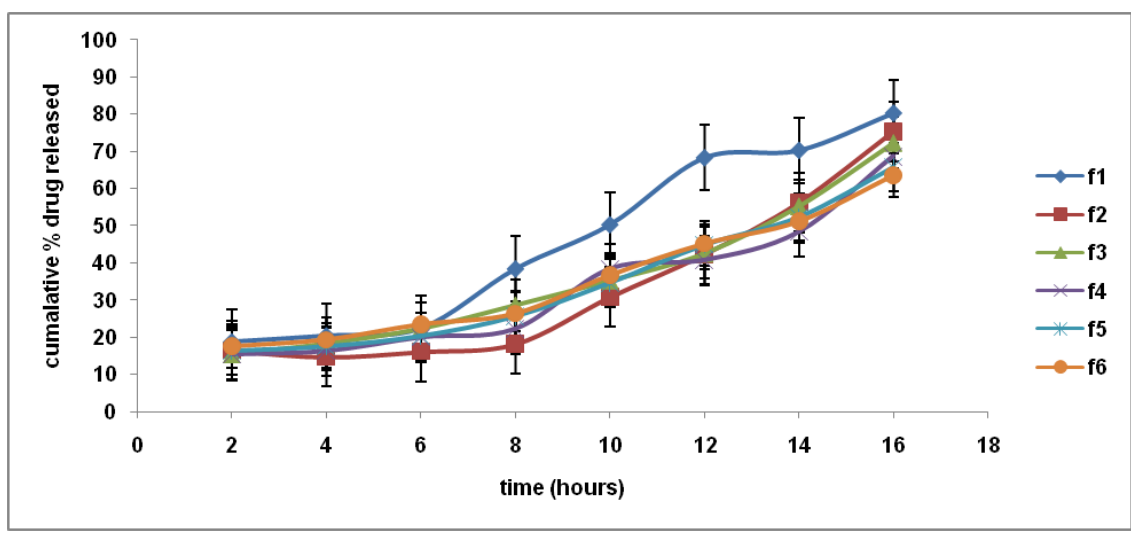

Fig. 5: In vitro drug release of dicofenace matrix tablet

The release data as given in table 5 was fitted to various mathematical models to evaluate the kinetics and mechanism of drug release. The kinetic data of all formulations $f-1$ to $f-6$ could be best expressed by zero order equation as the plots showed highest linearity ( $R^{2}: 0.902$ to 0.954$)$. The $n$ values obtained from Korsmeyer Peppas plots range from (0.804 to 1.122 ) indicate that mechanism of release from formulations f-1tof- 6 was polymer disentanglement and erosion.

Table 5: Release kinetic study diclofenac matrix tablets in $0.1 \mathrm{~N} \mathrm{HCl}$ at $37^{\circ} \mathrm{C}$

\begin{tabular}{|c|c|c|c|c|c|}
\hline \multirow[t]{2}{*}{ Formulations } & \multirow{2}{*}{$\begin{array}{l}\text { Zero order } \\
\left(\mathbf{R}^{2}\right)\end{array}$} & \multirow{2}{*}{$\begin{array}{l}\text { First order } \\
\left(\mathbf{R}^{2}\right)\end{array}$} & \multirow{2}{*}{$\begin{array}{l}\text { Higuchi } \\
\left(\mathbf{R}^{2}\right)\end{array}$} & \multicolumn{2}{|c|}{ Korsmeyer-Peppas } \\
\hline & & & & $\left(\mathrm{R}^{2}\right)$ & Slope n \\
\hline f1 & 0.954 & 0.915 & 0.961 & 0.942 & 1.122 \\
\hline $\mathrm{f} 2$ & 0.952 & 0.829 & 0.858 & 0.860 & 0.860 \\
\hline $\mathrm{f} 3$ & 0.928 & 0.937 & 0.894 & 0.963 & 0.861 \\
\hline $\mathrm{f} 4$ & 0.902 & 0.936 & 0.883 & 0.920 & 0.923 \\
\hline f5 & 0.939 & 0.936 & 0.928 & 0.946 & 0.944 \\
\hline f6 & 0.950 & 0.951 & 0.933 & 0.944 & 0.804 \\
\hline
\end{tabular}

\section{Stability studies}

On the basis of in vitro drug released characteristics $\mathrm{f}-6$ formulations was selected for stability studies. The test parameters were disintegration time, hardness, in vitro drug release and drug content. The results of stability study are shown in table 6, which indicates no remarkable change in the physical characteristics and release profile of the prepared formulation and was found to be stable for three months.

Table 6: Stability studies of $\mathrm{f} 6$ formulation at $40{ }^{\circ} \mathrm{C} \pm 2{ }^{\circ} \mathrm{C} / 75 \% \mathrm{RH} \pm 5 \%$

\begin{tabular}{|c|c|c|c|c|}
\hline \multirow[t]{2}{*}{ Parameter } & \multicolumn{4}{|l|}{ Days } \\
\hline & $\mathbf{0}$ & 15 & 30 & 60 \\
\hline In vitro drug release (\%) & 63.6 & 63.4 & 63 & 62.6 \\
\hline Hardness $\left(\mathrm{kg} / \mathrm{cm}^{2}\right)^{\mathrm{a}}$ & $6.0 \pm 0.01$ & $6.2 \pm 0.01$ & $6.0 \pm 0.01$ & $6.3 \pm 0.01$ \\
\hline Disintegration time $(\mathrm{min})^{\mathrm{a}}$ & $31 \pm 0.01$ & $32.3 \pm 0.11$ & $31 \pm 0.25$ & $30 \pm 0.06$ \\
\hline Drug content ${ }^{\mathrm{a}}$ & $98.7 \pm 0.21$ & $97.2 \pm 0.03$ & $98.2 \pm 0.11$ & $98.3 \pm 0.22$ \\
\hline
\end{tabular}

amean $\pm \mathrm{SD}, n=3$. 


\section{CONCLUSION}

The experimental data of the present research work carried out indicated the potential of Tinospora cardifolia mucilage as release retardant agent in the formulation of sustained release tablets of diclofenace. In vitro released studies of formulation f1-f6 showed, formulation f6 containing maximum amount of mucilage release the drug in a controlled and sustained manner with maximum amount of 63.6\% drug in $15 \mathrm{~h}$. Hence it is concluded that Tinospora cardifolia can be utilized as natural matrix forming agent in the formulation of sustained released tablets.

\section{AUTHORS CONTRIBUTIONS}

Ritima Sharma and Shivali Garg helped in the isolation and physico chemical characterisation of mucilage from the plant. Tejeswini Vasisht, Rajni Bala and Reecha Madaan were the main investigators of this project.

\section{CONFLICTS OF INTERESTS}

All authors have none to declare

\section{REFERENCES}

1. Prakash P, Porwal M, Saxena A. Role of natural polymer in sustained release drug delivery system: application and research approaches. Int Res J Pharm 2011;2:6-11.

2. Patil SV, Ghatage SL, Navale SS, Mujawar NK. Natural Binders in tablet formulation. Int J Pharm Tech Res 2014;6:1070-3.

3. Singh P, Laryia S. Modified kondagogu gum as matrix forming material for sustained released. Int J Curr Pharm Res 2016;8:82-7.

4. Patil DN, Kulkarni AR, Hatapakki BC, Patil BS. Preparation and evaluation of Aegle marmelos gum as a tablet binder. Int J Pharm Bio Sci 2010;1:1-5.

5. Macharla A, Velmurugan S, Rao V. Design and evaluation of torsemide controlled released matrix tablets. Asian J Pharm Clin Res 2015;8:159-63.
6. Babu R, Satheeskumar S, Shanmugasundara P, Shanmugam S. Formulation and evaluation of sustained release matrix tablets of levosulpiride. Asian J Pharm Clin Res 2017;10:285-92.

7. Joshi Y, Bhatt R, Bisht P, Juyal D, Sade S. Evaluation of Tinospora cordifolia mucilage as a novel tablet binder. World J Pharm Pharm Sci 2015;4:1113-23.

8. Bala R, Madaan R, Vibhu, Aneesh, Arora S. Isolation and evaluation of Hibiscus rosa sinensis leaf mucilage as superdisintegrant. Eur J Pharm Med Res 2016;3:434-40.

9. Gupta S, Parvez N, Sharma PK. Extraction and characterization of Hibiscus rosa sinensis mucilage as pharmaceutical aduvant. World Appl Sci J 2015;33:136-41

10. Jani GK, Shah DP. Evaluation of mucilage of Hibisus rosa sinensis linn as a rate controlling matrix for sustained release of diclofenac. Drug Dev Ind Pharm 2008;34:807-16.

11. Indian Pharmacopoeia, Ministry of Health and Family Welfare, Govt of India $4^{\text {th }}$ edition New Delhi: the Controller of Publication; 1996.

12. Behl AK, Dhake AS. Formulation and release characteristics of controlled release ofloxacin tablets. Indian Drugs 2005;42:316-8.

13. Vargas CI, Ghaly ES. Kinetic release of theophylline from hydrophilic swellabe matrices. Drug Dev Ind Pharm 1999; 25:1045-50.

14. Ranga RK, Padmalatha DK, Buri B. Cellulose matrices for zero order release of soluble drugs. Drug Dev Ind Pharm 1988;14:2299-320.

15. Korsemeyer RW, Peppas NA. In: Mansdorf SZ, Roseman TJ editors. Macromolecular and modeling aspects of swellingcontrolled systems. New York: Marcel Dekker Inc; 1983. p. 77.

16. ICH Harmonisation Tripartite Guideline. Cover note for revision of Q1A(R) Stability testing of new drug substance and products. Q1A (R2); 2003. p. 9.

17. Ayhan S, Yalcin O, Askin I. Preparation and in vitro evaluation of sustained release tablet formulation of diclofenac sodium. Farmaco 2005;60:171-7.

18. Bharadwaj TR, Kanwar M, Lal R, Gupta A. Natural gums and modified natural gums as sustained-release carriers. Drug Dev Ind Pharm 2000;26:1025-38. 